\title{
EDUCATION OF ISLAMIC AESTHETICS FOUND IN AL-QUR'AN SURAH AR-RAHMAN
}

\author{
Ali Fauzi \\ Institut Agama Islam Nahdlatul Ulama (IAINU) Tuban. \\ e-mail: alifauzi@stitmatuban.ac.id
}

\begin{abstract}
In Al-Qur'an Surah Ar-Rahman, The researcher finds Education of Islamic Aesthetics accumulated in figurative language. However, the Moslems just recite and do not try to know and to analyze it. The researcher chooses the title "Education of Islamic Aesthetics Found in Al-Qur'an Surah Ar-Rahman" and formulates the problem: How is the education of Islamic aesthetics found in Al-Qur'an Surah Ar-Rahman? The objective of the research is to describe the education of Islamic aesthetics he finds in Al-Qur'an Surah Ar-Rahman. The researcher hopes that this research will be useful for all sides. In order that he has knowledge about Education of Islamic Aesthethic in general and aesthetics in form of figurative language in special, he has to read many references as the basic of theories before. In the research, he uses phenomenological approach and in interpreting phenomena and facts, he uses hermeneutics.

The research is qualitative research in form of content analysis and the method of research is descriptive-text analysis. The data in this research is in form of words, phrases, sentences, and verses taken from the Holy Al-Qur'an surah Ar-Rahman. The researcher collects the data by observing the text of Al-Qur'an Surah Ar-Rahman, and documenting them based on the classification of education of Islamic aesthetics accumulated in figurative language. He then analyzes the data by reducting, presenting and concluding them so that the data he uses are really valid.

The researcher then describes the data of Education of Islamic aesthetics accumulated in form of figurative language he finds in the Al-Qur'an surah Ar-Rahmanelaborated in many kinds of figure of speech such as alliteration, antithesis, euphemism, personification, hyperbole, pleonasm, irony, antonomasia and apophasis. The researcher describes the data and analyzes them one by one using hermeneutics in the discussion. The researcher then concludes that in Al-Qur'an surah Ar-Rahman, he finds education of aesthetics the moslems must know. He also suggests the Moslems to recite and analyze it in order to get deep understanding on the verses and Surah Ar-Rahman.
\end{abstract}

Keywords: Aspect, Education, Aesthetics, Al-Qur'an, Surah Ar-Rahman.

\section{INTRODUCTION}

Many Ulama have different opinions on the definition of Al-Qur'an. Some say that Al-Qur'an is the utterance of Allah in form of miracle descended to the Prophet of Muhammad through the mediator of the angel Gabiel. However, the words, verses, pronounciation, and meaning of AlQur'an are from Allah. Reciting Al-Qur'an is worship; Al-Qiur'an starts from the surah Al-Fatihah and ends with the surah An-Nas. Al-Qur'an is the speech of Allah written in Arabic Mushaf which was descended to the Prophet of Muhammad as the miracle or good barometer of people life by the mediator of Gabriel (Shihab, 2008: 13). While, Surah Ar-Rahman is the name of fifty fifth surah in Al-Qur'an and this surah consists of 78 verses which was descended in Mecca so that it is called 
surah makkiyah. Surah Ar-Rahman is called Ar-Rahman which means The Most Generous and The Most Merciful. The word Ar-Rahman is taken from the word Ar-Rahman found in the first verse of Al-Qur'an surah Ar-Rahman. Ar-Rahman is one of the names of Allah.

Major parts of surah Ar-Rahman explain the generosity of Allah to His created beings. He has given all to them, enjoyments and all things in the world and in Hereafter. Surah Ar-Rahman is also known as “Arus Al-Qur'an", which in general it means bridal couple of Al-Qur'an as the prophet Muhammad said; "everything has bridal couple and the bridal couple of Al-Qur'an is surah ArRahman. The name given is the special characteristics of surah Ar-Rahman because of the beauty of the surah and it is detected in the sentence "Fa-biayyi alaa'i Rabbi kuma tukadzdzi ban" (then which the favor from Allah do you lie about?) in which it is considered as the jewels used by newly wed couple. Therefore, this sentence is presented 31 times and put by the end of each verses telling the favors Allah has given to human beings (Az-Zuhaili, 2014: 224). The verses of the Surah ArRahman which becomes the special characteristic was also read by the Prophet of Muhammad before Allah commanded him to spread the teaching of Islam openly. While for the ones who do not do their religious teaching well, Surah Ar-Rahman as Allah said contains warning in form of a sentence “Then which the favor from Allah do you lie about? (Abdullah: 2007).

Al-Qur'an Surah Ar-Rahman starts with the verse showing the proof, sign and manifestation. Sign is a thing which represents or refers to other things and functions as the basis of interpretation as a proof that there is relationship with things represented. Language as a system of sign has two related elements that is a thing used as a sign which may be in form of sound or symbols and a sign which is the element of the concept or meaning found in the sign (Abrams, 1981:195). The first proof and sign is the word Ar-Rahman meaning Allah the Merciful, teaching knowledge of Himself through Al-Qur'an (Al-Mizan). While, manifestation is the sign functioning to analyze, to think, and to feel on the object in the text which is difficult to choose relationally (Abrams in Burhan Nurgiyantoro, 1998: 42-43). The first manifestation of Allah is His light, His character and His light of knowledge. Non Moslems put the light and the command of Allah off but Allah does not permit it because "Allah is the light of the sky and the earth" (Q.S. An-Nur: Verse 5). Surah Ar-Rahman ends in the sentence of "The All Blessing" (tabaraka) meaning one of Allah names. If human beings call the name of Allah, Allah will approach their houses-the place where they call the name of Allah.

Al-Qur'an Surah Ar-Rahman contains Islamic educations. The First is education of faith (Aqidah) in which Allah teaches human beings to speak well; trees and plants to obey, the universe and all in it are the bless from Allah given to human beings. The second is education of Akhlak (Morality) which leads the deed, the behavior of human beings and warns in form of guideline. The third is education of Fiqih (Islamic law) which asks human beings to measure, to weigh something justly. 
The fourth is education of Tarikh (Islamic history) which contais the history of human beings and genies who are under the control of Allah. Many things happen and will happen as Allah's will like the canal of Suez and Panama (Az-Zuhaili, 2014: 226-227). However, all the Islamic educations are reflected from figurative language so that the researcher just discusses education of Islamic aesthetic accumulated in figurative language.

The superiority of Al-Qur'an Surah Ar-Rahman is stated in Hadits in which Rasulullah said: "Whoever recite the surah Ar-Rahman, Allah will love his weaknesses and bless the blessings on him." Then Imam Ja'far Ash-shadiq said: "Whoever recite surah Ar-Rahman, and when he recites the sentence "Fabiayyi âlâi Rabbikumâ tukadzdzibân", he utters: "Lâ bisyay-in min âlâika Rabbî akdzibu" (none of your favor, O my Allah, that I lie), when he recites it in the night then he dies, then his death is martyred; When he recites it in the day then he dies, then his death is like martyred." Then Imam Ja'far Ash-Shadiq repeated: “Do not stop reciting Surah Ar-Rahman, wake up at night with him, this Surah does not amuse the hearts of hypocrites, you will find Allah with him on the Day of Judgment, his form is like beautiful human form, and it smells the most fragrant. On the Day of Judgment no one stands in front of Allah closer to Him than him" (Barqi: 1371H).

Substantively Surah Ar-Rahman contains Islamic aesthetics in form of figurative language reflected in the context of language and meaning implied in the beautiful language and many other methaphoric expressions and the beauty of the meaning impled in the words wrapped in the subtlety of the language. All the figurative languages are reflected in the words, sentences, and language of great literature put in the Holy Al-Qur'an. The elements and the aspects figurative language found completely in the Holy Al-Qur'an will be meaningful and contain the enjoyment for the reciters and analyzers because they may get inner peace deeply (Wellek dan Austin Warren, 2014: 178-198). However, many Moslems just recite Al-Qur'an and do not know about the content of education of Islamic aesthetics in form of figura tive language in it. Therefore, the researcher is interested in discussing it and tries to describe education of aesthetics in form of figurative language found behind the beauty of language and meaning in Al-Qur'an Surah Ar-Rahman. The researcher has also motivation to research it because of the prominence and benefit of reciting Al-Qur'an Surah ArRahman from which he decides to choose the title "Education of Islamic Aesthetics Found in AlQur'an Surah Ar-Rahman" as the main discussion and abstraction in this research.

The researcher also hopes that this research will stimulate further researchers to discuss other sides of The Holy Al-Qur'an and classical books in the academic institution. To make the discussion easy to do, the researcher formulates the problem: How is education of Islamic aesthetics found in Al-Qur'an Surah Ar-Rahman?. By this, the objective of the research is to describe education of Islamic aesthetics found in Al-Qur'an Surah Ar-Rahman. Of course, the researcher hopes that the 
research will be useful for the readers. At least it will be the additional reference and reading material to add knowledge which enables us to have new inspiration and new research ideas. He also wants it to motivate the reciters of Al-Qur'an to know and to analyze the meaning of the verses in order that they may get complete understanding and knowledge.

\section{RESEARCH METHOD}

The approach of this research is phenomenological approach in which the researcher tries to find and to interpret the facts and the causes of things based on the phenomena and the researcher's view although it may be subjective (Arifin, 1994: 46-47). On account of the fact that the researcher uses phenomenological approach and he must interpret phenomena in the text, so he uses hermeneutic - a method in understanding and in interpreting phenomena in the text by the use of language - in the discussion and the description of data (Ratna, 2004: 44-45). It means that the researcher tries to observe education of Islamic aesthetics reflected from the words, sentences, and verses in the Al-Qur'an Surah Ar-Rahman based on his own interpretation. In the research, the researcher functions as the main instrument, the data are analyzed inductively, stresses on the process more than the result, focuses on the main points of discussion and recapitulates the data based on the criteria and the valid data are discussed simultaneously (Moleong, 2017 4-8). Qualitative research uses approach which orientates on the natural symptoms, so it cannot be done in the laboratory but in the relation with the text. Theoretical orientation becomes the basic of thinking to understand the meaning and to interpret classical text or social reality in the past in order to be appropriate for each time. Hermeneutic includes three subjects related one another, the world of the text, the world of the author and the world of the reader in which they have their own scope supporting each other in understanding text (Mulyono, 2012: 100).

The research is library research in form of content analisis. It means the researcher analyzes the content of Al-Qur'an Surah Ar-Rahman and describes education of aesthetics in the text as material analysis to prove that in Al-Qur'an Surah Ar-Rahman he finds education of Islamic aesthetics from which the aesthetics is elaborated in several figure of speeches. The researcher analyzes the data of research in three phases. The first is data reduction- the process of selecting, focusing and transforming raw data in Al-Qur'an Surah Ar-Rahman. The second is data descriptiondescribing all finding data enabling him to understand the phenomena and aesthetics in form of figurative language in the text. The third is data conclusion - done after doing data verification (Miles and Huberman, 1984: 48-51). He also finds data from many literatures to get theory and principle as the secondary data used as a means to analyze it (Suharsimi Arikunto, 2002:23). The method used is deskriptif-textual analysis. It is done because the object he analyzes is in form of text that is the language in verses of Al-Qur'an Surah Ar-Rahman containing education of aesthetics 
(Bogdan dan Biklen in Moleong, 2017: 3). The method of analysis describes phenomena in the text through collecting data, analyzing data and interpreting data so that the research will be valid and reliable (Surahmad, 1972: 131).

The Data is in form of verses, language, phenomena, facts, information, and source of data is AlQur'an Surah Ar-Rahman as primary data and other books related to it as the secondary data (Arikunto, 1989: 102). In collecting data, he uses the technigue of observation and documentationtechnique of observing and recording systematically on the aspects in the symptoms in the object of research (Nawawi dan Martini, 1992:74). By this technique, the researcher understands and knows education of Islamic aesthetics in form of figurative language found in the Al-Qur'an surah ArRahman and the researcher himself acts as main instrument. The researcher combs the text AlQur'an Surah Ar-Rahman and arranges systematically the quotations in order to be easy to analyze. In analyzing data, he does it through, data reduction, data display and Conclusion Drawing/verification. In fact before data conclusion, the researcher must recheck many times on the validity of them by crosschecking, confirming, and sinchroning data in the text of Al-Qur'an Surah Ar-Rahman.

\section{RESULT AND DISCUSSION}

\section{Education of Islamic Aesthetics Found in Al-Qur'an Surah Ar-Rahman}

Before discussing education of Islamic aesthetics in Al-Qur'an Surah Ar-Rahman, it is better to know the terms first. The word Aesthetics is taken from the Greek word "aesheton" meaning the ability of seeing by sensation, perception, feeling, experience and thought. From the word aesheton then it comes up the word "aesthesis" or observation of which it is the branch of philosophy having the object of sense experience and talking about beauty systematically either in the side of art or in the side of form, essence and effect of the art (Liberman dan Foster, 1990: 1) In aesthetic we find the essence of beauty, form and sense of beauty like the physical and nonphysical beauty, natural beauty and art beauty to which human beings investigate based on their emotion toward beautiful, noble, tragic, good and touching things (Surajiyo, 2005: 101). Aesthetic belongs to the sensory knowledge that is the knowledge of sense-not logic- which is related to the perception on the sense of beauty, specially the beauty of the art work. Aesthetic may be defined as the element of beauty reflected from the language and implied meaning using symbols, and signs which refer to the aspects of its basic of literature (Teeuw, 1988: 346-347).

Islamic aesthetic is the beauty which can be presented in many kinds of forms and ways which leads human to have noble values based on the religious teaching. Therefore, Islam can accept many kinds of beautiful expressions as long as they are not against the value of al-Khair and alMa'ruf, that is the universal value which Islam teaches and local and temporal values based on the 
social culture. The prophet Mohammad said "Allah The Most Beautiful and The Most Like Beauty". He gives human the feeling of beauty lover. Therefore, it is impossible for Him to forbid the art except it has bad effect. Even Imam Al-Ghazali said that whoever must like the green plants and beautiful flowers and beautiful of music sound. Allah must permits the existence of every work, will and feeling leading to the goodness but forbids it if it leads to the badness. Whoever gathers the beautiful things and Allah, so his effort is categorized Islamic art but if it does not match with Him, so it is not Islamic art. In Islam we do not use "Art for Art" because for Moslems all action and silence must be intended to Allah "My Shalat, my good deeds, my life and death are just for Allah SWT” (QS. Al-An'âm [6]: 162).

Islamic aesthetics found in Al-Qur'an Surah Ar-Rahman is in form of figurative language. Endraswara (2003:73) says that "figurative language is the art controlled by feeling and beauty taken from in one unit of feeling within the writer." Keraf (2004:112) said that "figurative language is said to be the talent of a writer in analyzing words and describing them in form of beautiful writing." It may be the way of using language and expressing something in order that it can attract and express more (Sumardjo \& Saini K.M., 1986: 127). Figurative language is the special ways the writer uses in expressing his ideas in form of literay work by means of writing in which the words are arranged in such a way that they do not directly state the original meaning. Figurative language is the act of choosing and using the words according to the content one would like to say. It is the act of how to arrange the sentences effectively and aesthetically which may give concrete description in the mind of the readers (Tjahyono, 1988: 201). Figure of speech is the expression that gives variety or force, using word out of their literal meaning (Fauzi, 2002: 17). Figurative language is the special way the writer uses in pouring his ideas in form of literary work by using writing. The writer with his competence uses words to create the beauty of sentences. He explains his ideas using analogy expressed in different way so that it attracts to things said for which it in literature is called metaphor. Al-Qur'an is not literary work but it is the Commandment of Allah which has beautiful language; words, phrases, sentences. Because Al-Qur'an uses literary language, Al-Qur'an especially surah Ar-Rahman has educated Moslems through the polite language leading to the education of aesthetic in form of figurative language in which major parts of the moslems who recite it do not know.

\section{Alliteration}

Alliteration is the figurative language in form of the repetition of similar sound in the words or sentences placed closely together which may cause dramatic effect or beauty (Fauzi, 2002: 37). It is the repetition of the same sound at the beginning of several words which are near one another. In Al-Qur'an surah Ar-Rahman, we find figurative language in form of alliteration - the repetition of 
sound in the words or sentences or verses. Figurative language found in Al-Qur'an surah ArRahman is three kinds that is the repetition of word الْمِيْزَانِ as it is seen in the verses $7^{\text {th }}-8^{\text {th }}$, the

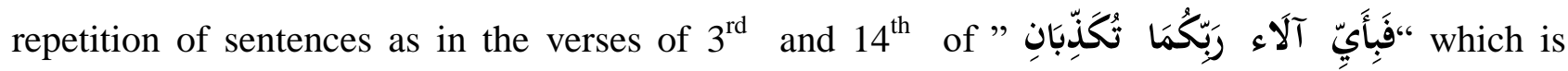
expressed 31 times in the verses $13^{\text {th }}, 16,18,21,23,25,28,30,32,34,36,38,40,42,45,47,49$, $51,53,55,57,59,61,63,65,67,69,71,73,75$, and 77 , as it is seen in the following quotation:

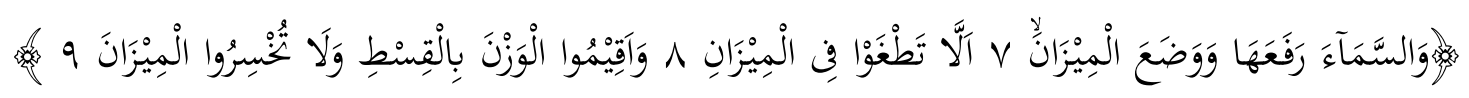

In the quotation above, the researcher finds the repetition of sound of the word meaning "Pair of Scales" recited 3 times in different verses, verses $7^{\text {th }}, 8^{\text {th }}$ and $9^{\text {th }}$. The repetition of sound or word الْمِيْزَانِ in the verse is poetical language and it belongs to alliteration. The repetition of the sound or word causes of beauty in the listeners. Besides the repetition of sound in form of a word, we also find the repetition of sound in form of sentence as it is found in the verses 3th and $14^{\text {th }}$ of the quotation below:

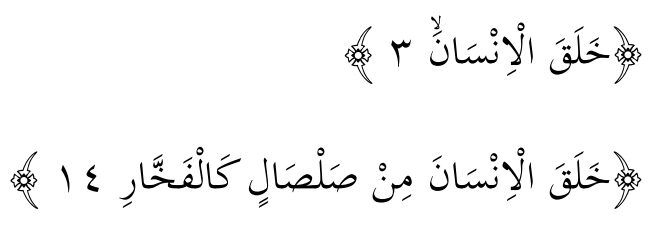

In the above quotation, the researcher finds the repetition of sound in form of sentence

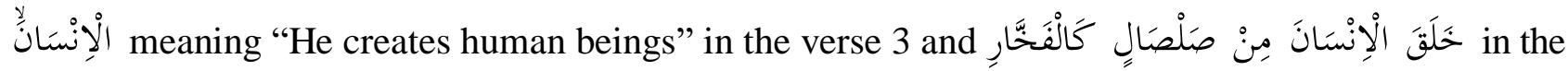
beginning of sentence (verse 14) meaning "He creates human beings from the clay like like porcelain" (Az-Zuhaili, 2014: 227 \& 234). The repetition of sound in form of a sentence in the different place is also figurative language which creates beauty and forms variety.

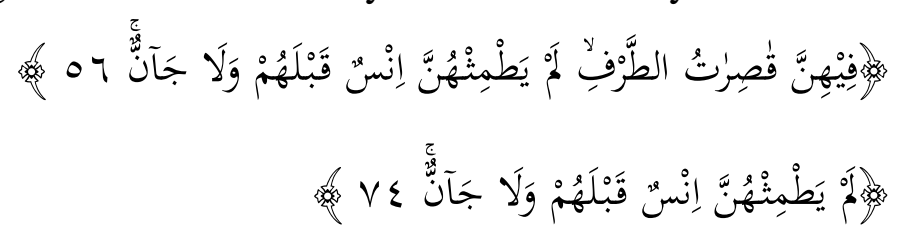

In the above quotation, the researcher finds the repetition in form of a sentence

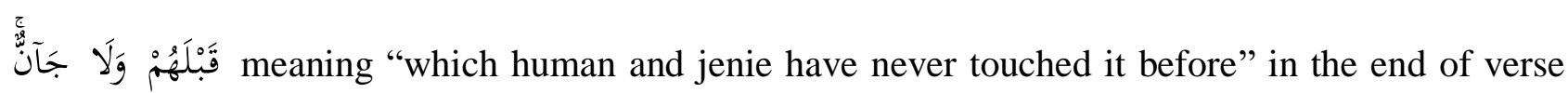

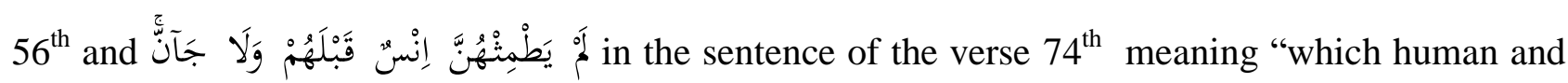


jenie have never touched it before" (Az-Zuhaili, 2014: 252 \& 260). The repetition of sound in form of sentence in the different place is also figurative language which creates beauty and form the variety of sentence. The researcher also finds repetition of sound in form of verse as it is seen in the following quotation:

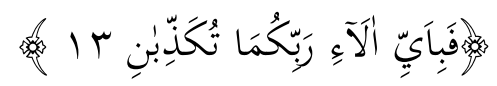

In the quotation above, the researcher finds verse فَبَأَيّ آَلاء رَبّكُمَا تُكَذِّبَانِ meaning “Then which the favor of your Allah do you lie about?" (Az-Zuhaili, 2014: 227) recited 31 times in the verses $13^{\text {th }}, 16,18,21,23,25,28,30,32,34,36,38,40,42,45,47,49,51,53,55,57,59,61,63$, $65,67,69,71,73,75$, and $77^{\text {th }}$. The repetition of sound in form of verses are in the different places and in the first part of surah Ar-Rahman to the last part.

\section{Antithesis}

Antithesis or the use of opposite terms very closely together is a figurative language which contains the opposite word or sentence (Tjahyono, 1988: 214). In order to create tension the writer may present ironic coupling of opposites. It is the result when a pair or more of strongly contrasting terms are presented together. If words, ideas, or clauses are widely divergent but present together, there is a certain amount of resulting tension which makes the line highly provocative. In Al-Qur'an surah Ar-Rahman verse $17^{\text {th }}$, we find antithesis in form of using two opposite words as it is seen in the quotation below:

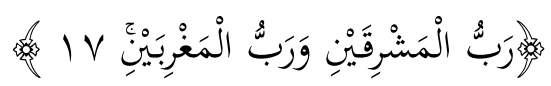

In the quotation above, we find figurative language in form of antithesis, in the word الْمَشْرََِيْنِ

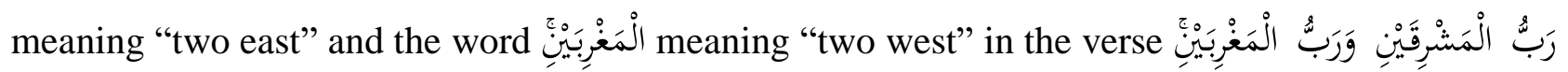
meaning "Allah (who take care) two east and Allah (who takes care) two west" (Az-Zuhaili, 2014: 234). The words rise and set whose place is close is antithesis which has the effect of sound beauty.

\section{Euphemism}

Euphemism is a figurative language using words other than the real meaning with the hope that it will be politer (Tjahyono, 1988: 204). It is the substitution of an inoffensive or mild expression for one that may offend or suggest something unpleasant. It is a kind of the elaborate way of saying something. Sometimes the writer uses embellishing language, making everything seem more romantic, exotic, or wondrous than in reality or than when described in literal language (Fauzi, 
2002: 37). In Al-Qur'an surah Ar-Rahman we find figurative language in form of euphemism which intends to make the language politer. This can be seen from the verse $10^{\text {th }}$ to the verse $12^{\text {th }}$ surah $\mathrm{Ar}$ Rahman below:

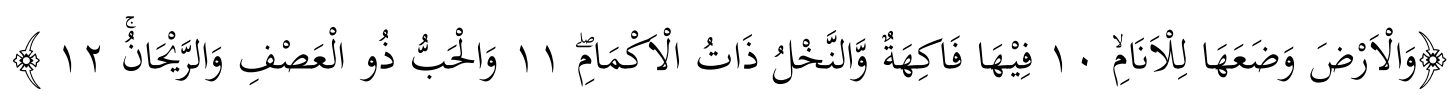

In the above quotation, we find 3 verses belonging to euphemism. The first فِيْهَا

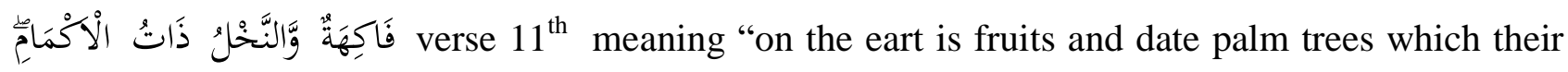

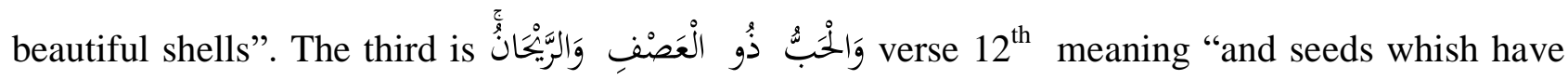
shells and fragrant flowers" (Az-Zuhaili, 2014: 227).

\section{Personification}

Personification is a part of figurative language which figurates unloving things to become living things and have activities, intention and desire like human beings (Tjahyono, 1988: 202). It is inanimate objects or abstract ideas are spoken of as if there were persons. It is the attribution of lifelike or human attributes to inanimate objects or ideas. It is figurative language making unloving thing as if it can move or has the character like human or attributed like human. In Al-Qur'an surah Ar-Rahman verses $6^{\text {th }}$ and $19^{\text {th }}$, we find figurative language in form of personification as it is seen in the quotation of verse below:

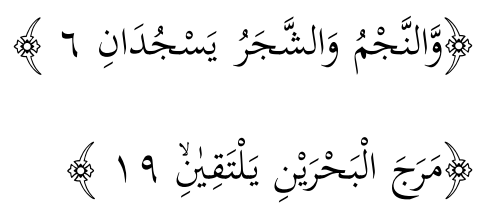

The above quotation has 2 verses belonging to figurative language in form of personification. The first is وََّالنَّجْمُ وَالشَّْجرُ يَسْجُجُدَانِ meaning “and plants and trees, both obey (to Him)". The second is مَرَج الْبَحْرَيْنِ يَلْتَقِينِن meaning "He lets the two oceans flow which (then) both meet" (Az-Zuhaili, 2014: 227 \& 234).

\section{Hyperbole}

Hyperbole is figurative language which states a thing or condition redundantly (Tjahyono, 1988: 204). It is a statement which exaggerates by saying more than is literally meant. The overstatement is not made for the purpose of deceiving but for the sake of emphasis. The figurative 
language tries to express something redundantly more than the reality as it is seen in the quotation below:

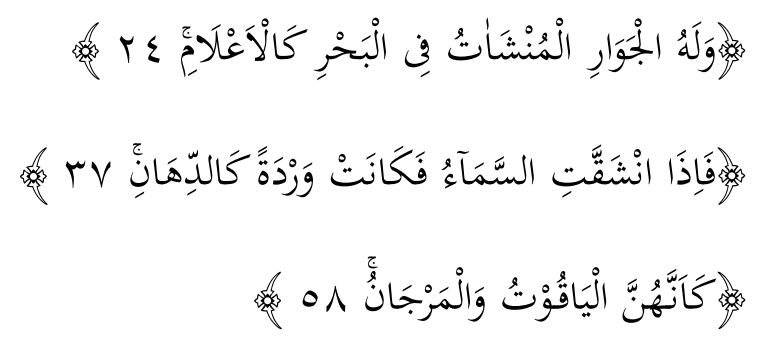

The above quotation has 3 verses belonging to the figurative language in form of hyperbole.

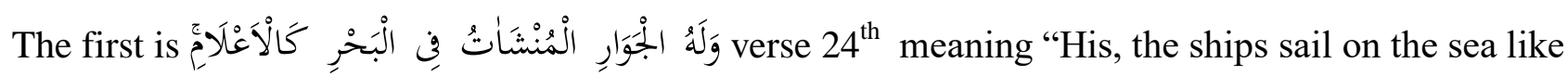

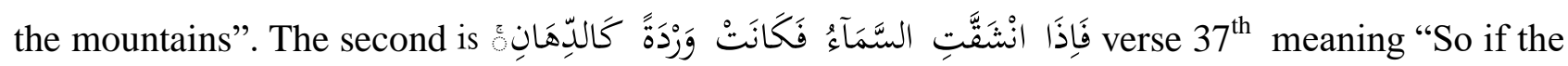

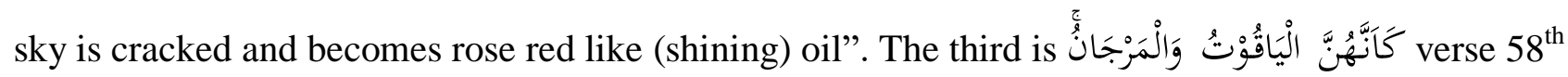
meaning "as though they (fairies) are sapphires and jewels (Az-Zuhaili, 2014: 232,247,252).

\section{Pleonasm}

Pleonasme is figurative language which emphasizes and explains a word which it should not be reexplained because of the clear meaning (Tjahyono, 1988: 206-207). In Al-Qur'an surah ArRahman we find figurative language in form of Pleonasm in the phrase أَيَّْ النَّقَْْنِ meaning "For you the (species of) human beings and genie” in the verses $31^{\text {st }}$ meaning “we will give attention wholly for you the (species of) human and genie!" (Az-Zuhaili, 2014: 232).

\section{Irony}

Irony is figurative language used to tease others politely using the words in contrast to the real ones (Tjahyono, 1988: 212). It is a statement which expresses the opposite idea which one desires to convey. It is ridicule transparently disguised as a compliment. Irony is often used in daily life to make a fun. But in this case, Irony is not used to make a fun instead it is used to warn politely on the behavior of human beings, as it is seen in the quotation from Al-Qur'an surah Ar-Rahman below:

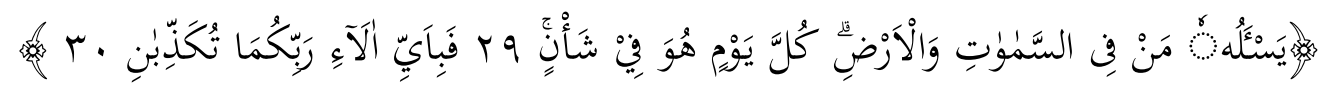

In the quotation above, the researcher finds figurative language in form of irony in the

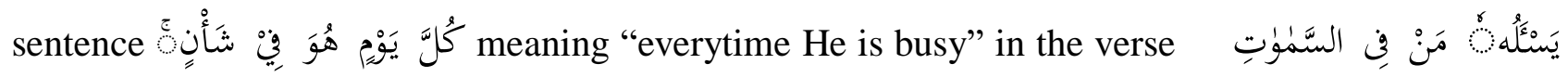




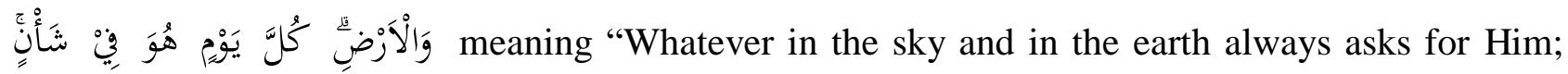
everytime He is busy”. Besides it, he also finds irony in the verse فَبَاَيّ الَآٍَ رَبّكُمَا تُكَذِِّبنْ meaning “then the favor of your Allah which do you lie about?” (Az-Zuhaili, 2014: 232).

\section{Antonomasia}

Antonomasia is figurative language calling the name of someone using other call in line with the character or type of him (Tjahyono, 1988: 206). Antonomasia is figurative language used to change the name and the honorable title. In Al-Qur'an Surah Ar-Rahman the researcher finds this figurative language antonomasia in the verse آلرَّحْمَن meaning "The Merciful”. The use of the word آلرَّحْمُن (the Merciful) is to change the name of Allah.

\section{Apofasis}

Apofasis is figurative language done by describing the writer's statement in stressing something but it is to reject. It may be said that the writer pretends to let it bygone but he in fact emphasizes it (Habib, 2004: 156). It can be seen in Al-Qur'an surah Ar-Rahman verse $33^{\text {rd }}$ below:

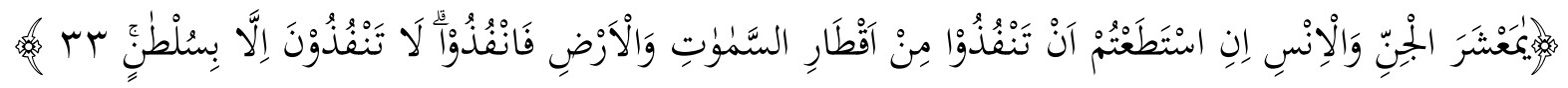

In the quotation above, the researcher finds figurative language in form of apofasis in verse meaning “if you are able to penetrate (to cross) over the sky and earth, please do it". The complete meaning of the verse is "O genie and man! If you are able to walk (to cross) over the sky and the earth, please do it. You can not do it except with the power of (from Allah )" (Az-Zuhaili, 2014: 232).

\section{CONCLUSION}

Based on the description of the discussion above, the researcher concludes that in Al-Qur'an surah Ar-Rahman the researcher finds education of Islamic aesthetics in form of figurative language consisting of several kinds implied as a means of explaining the love of Allah to His creatures especially human beings and genie. Through the beauty of His language, Allah teaches, reminds, commands and forbids them by the use of polite language. Education of aesthetics in form of Figurative language in Al-Qur'an Surah Ar-Rahman is implied in form of alliteration, personification, antonomasia, for example the material of moral explaining the deed of human beings is packed in irony and apofasis, material Islamic law is packed in alliteration and material of 
Islamic history explaining about the history and Islamic story is packed in alliteration, anthitesis, euphemism, personification and hyperbole.

\section{REFERENCE}

Abdullah, M. 2007. Tafsir Ibnu Katsir Jilid 13. Bogor: Pustaka Imam Asy-Syafi'i.

Abrams MH. 1981. A Glossary of Literary Terms. London: Holt, Rinehart and Winston

Arifin, Imron (ed). 1994. Penelitian Kualitatif dalam Ilmu-ilmu Sosial dan Keagamaan. Malang: Kalimasada Press.

Arikunto, Suharsini. 2002. Prosedur Penelitian Suatu Pendekatan Praktek. Jakarta: Rineka Cipta.

Az-Zuhaili, Wahbah. 2014. Tafsir Al-Munir. Aqidah, Syari'ah, \& Manhaj Jilid 14. Jakarta: Gema Insani.

Barqi, Ahmad bin Muhammad. 1371H. al-Mahāsin. Tehran: Darul Kutubul Islamiyah.

Endraswara, Suwardi. 2003. Metodologi Penelitian Sastra. Yogyakarta : Caps.

Fauzi, Ali. 2002. Intruduction To Literature. Tuban: IKIP PGRI Tuban Press.

Hornby, A.S. 1980. Oxford Advanced Learner's Dictionary of Cerrent English. London: The English Language Book Society and Oxford Univercity Press.

Jones, Jr. Edwarss H. 1968. Outline of Literature. New York: The Macmillan Company.

Keraf, Gorys. 2004. Diksi dan Gaya Bahasa. Jakarta : Gramedia Pustaka Utama.

Liberman, M.M. and Edward E. Foster. 1990. A Modern Lexicom of Literary Term. USA: Scott, Foresman and Company.

Miles, Matthew B \& Michael Huberman. 1984. Analisi Data Kualitatif Bahasa; Tjejep Rohendi Rohidi. Jakarta: Universitas Indonesia.

Moleong, J. Lexy. 2017. Metodologi Penelitian Kualitatif. Bandung: PT. Remaja Rosdakarya.

Mulyono, Edi Dkk. 2012. Belajar Hermeneutika: Dari Konfigurasi Filosofis Menuju Praktis Islamic Studies. Jogjakarta: IRCiSoD.

Nawawi, Hadari dan M. Martini Hadari. 1992. Instrumen Penelitian Bidang Sosial. Yogyakarta: Gadjah Mada University Press.

Nazir, Muhammad. 1986. Metode Penelitian. Bandung: Remaja Rosdakarya.

Nurgiyantoro, Burhan. 1998. Teori Pengkajian Fiksi. Yogyakarta: Gadjah Mada Univercity Press. 
Ratna, Nyoman Kutha. 2004. Teori, Metode, dan Teknik Penelitian Sastra. Yogyakarta: Pustaka Pelajar.

RI, Departemen Agama. 2010. Al-Qur'an dan Tafsirnya, Jilid. IX. Jakarta: Lentera Abadi.

Shihab, M. Quraish, et. All. 2008. Sejarah dan Ulum Al-Qur'an. Jakarta: Pusataka Firdaus.

Shihab, Quraish. 2009. Tafsir Al-Misbah, Ciputat: Lentera Hati.

Shihab, Quraish. 2012. Al-Lubab makna, tujuan, dan pelajaran dari surah-surah al-Qur'an, Ciputat: Lentera Hati.

Sumardjo, Yakob \& Saini K.M. 1988. Apresiasi Kasusastraan. Jakarta: PT. Gramedia.

Surachmad, Winarno. 1972. Pengantar Penelitian Ilmiah Dasar. Bandung: Tarsito.

Surajiyo. 2005. Ilmu Filsafat Suatu Pengantar. Jakarta: Bumi Aksara.

Teeuw, A. 1988. Sastra dan Ilmu Sastra: Pengantar Teori Sastra. Bandung: PT. Pustaka Jaya.

Tjahyono, Liberatus Tengsoe. 1988. Sastra Indonesia: Pengantar Teori dan Apresiasi. Ende: PT. Nusa Indah.

W, Ahsin. 2008. Kamus Ilmu Al-Qur'an. Jakarta: Amzah.

Wellek, Rene dan Austin Warren. 2014. Teori Kesusastraan. Jakarta: PT. Gramedia Pustaka Utama.

Zuhri, Minan. 1981. Pelajaran Tajwid. Kudus: Menara Kudus. 